\title{
A research synthesis of therapeutic interventions for whiplash-associated disorder (WAD): Part 5 - surgical and injection-based interventions for chronic WAD
}

\author{
Robert W Teasell $\mathrm{MD}^{1,2,3}$, J Andrew McClure BA ${ }^{1}$, David Walton PhD candidate ${ }^{4}$, Jason Pretty BA ${ }^{1}$, \\ Katherine Salter BA ${ }^{1}$, Matthew Meyer BA ${ }^{1}$, Keith Sequeira $\mathrm{MD}^{2}$, Barry Death $\mathrm{MD}^{2}$
}

RW Teasell, JA McClure, D Walton, et al. A research synthesis of therapeutic interventions for whiplash-associated disorder (WAD): Part 5 - surgical and injection-based interventions for chronic WAD. Pain Res Manage 2010;15(5):323-334.

Whiplash-associated disorder (WAD) represents a significant public health problem, resulting in substantial social and economic costs throughout the industrialized world. While many treatments have been advocated for patients with WAD, scientific support regarding their effectiveness is often lacking. A systematic review was conducted to evaluate the strength of evidence associated with various WAD therapies. Multiple databases (including Web of Science, EMBASE and PubMed) were searched to identify all studies published from January 1980 through March 2009 that evaluated the effectiveness of any well-defined treatment for acute (less than two weeks), subacute (two to 12 weeks) or chronic (more than 12 weeks) WAD. The present article, the fifth in a five-part series, evaluates the evidence for surgical and injection-based interventions initiated during the chronic phase of WAD. Twenty-five studies were identified that met the inclusion criteria, six of which were randomized controlled trials with 'good' overall methodological quality (median Physiotherapy Evidence Database score of 7.5). For the treatment of chronic WAD, there was moderate evidence supporting radiofrequency neurotomy as an effective treatment for whiplash-related pain, although relief is not permanent. Sterile water injections have been demonstrated to be superior to saline injections; however, it is not clear whether this treatment is actually beneficial. There was evidence supporting a wide range of other interventions (eg, carpal tunnel decompression) with each of these evaluated by a single nonrandomized controlled trial. There is contradictory evidence regarding the effectiveness of botulinum toxin injections, and cervical discectomy and fusion. The evidence is not yet strong enough to establish the effectiveness of any of these treatments; of all the invasive interventions for chronic WAD, radiofrequency neurotomy appears to be supported by the strongest evidence. Further research is required to determine the efficacy and the role of invasive interventions in the treatment of chronic WAD.

Key Words: Chronic pain; Chronic whiplash-associated disorder; Evidencebased medicine; Injections; Neck pain; Randomized controlled trials
Une synthèse de la recherche sur les interventions thérapeutiques à l'égard des troubles liés aux coups de fouet cervicaux (TCFC) : Partie 5 - Les interventions chirurgicales et par injection en cas de TCFC chroniques

Les troubles liés aux coups de fouet cervicaux (TCFC) représentent un problème important en santé publique, associé à des coûts sociaux et économiques substantiels dans le monde industrialisé. De nombreux traitements sont préconisés pour les patients ayant des TCFC, mais souvent, on ne possède pas de données scientifiques probantes en étayant l'efficacité. Les chercheurs ont procédé à une analyse systématique pour évaluer la qualité des preuves associées aux diverses thérapies des TCFC. Ils ont effectué des recherches dans de multiples bases de données (y compris Web of Science, EMBASE et PubMed) pour repérer toutes les études publiées entre janvier 1980 et mars 2009 qui évaluaient l'efficacité de tout traitement clairement défini en cas de TCFC aigu (moins de deux semaines), subaigu (de deux à 12 semaines) ou chronique (plus de 12 semaines). Le présent article, cinquième d'une série de cinq, vise à évaluer les données probantes liées aux interventions chirurgicales et par injection amorcées pendant la phase chronique des TCFC. Les chercheurs ont repéré 25 études respectant les critères d'inclusion, dont six étaient des essais aléatoires et contrôlés à la qualité méthodologique globale «bonne » (indice médian de la base de données probantes en physiothérapie de 7,5). Pour traiter un TCFC chronique, des données modérées indiquent que la neurotomie par radiofréquence est un traitement efficace des douleurs liées aux coups de fouet cervicaux, même si le soulagement n'était pas permanent. Il est démontré que les injections d'eau stérile donnent de meilleurs résultats que celles de soluté physiologique, mais on ne sait pas si le traitement est vraiment bénéfique. Des données soutenaient une vaste gamme d'autres interventions (p. ex., décompression du canal carpien), chacune d'elle ayant été évaluée par un seul essai non aléatoire et contrôlé. Des données contradictoires portaient sur l'efficacité des injections de toxine botulique, de discectomie cervicale et de fusion. Les données ne sont pas encore assez solides pour établir l'efficacité de l'un ou l'autre de ces traitements. De toutes les interventions effractives de TCFC chronique, la neurotomie par radiofréquence semble être étayée par les données les plus solides. D'autres recherches s'imposent pour déterminer l'efficacité et le rôle des interventions effractives dans le traitement des TCFC chroniques.

${ }^{1}$ Lawson Health Research Institute; ${ }^{2}$ Department of Physical Medicine and Rehabilitation, Parkwood Hospital, St Joseph's Health Care; ${ }^{3}$ Schulich School of Medicine and Dentistry; ${ }^{4}$ School of Physical Therapy, Faculty of Health Sciences, University of Western Ontario, London, Ontario

Correspondence: Dr Robert W Teasell, Department of Physical Medicine and Rehabilitation, Parkwood Hospital, St Joseph's Health Care,

801 Commissioners Road East, London, Ontario N6C 5J1. Telephone 519-685-4000 ext 44559, fax 519-685-4023,

e-mail robert.teasell@sjh.london.on.ca 
$T^{h}$ he term 'whiplash-associated disorder' (WAD) describes the consequences of a whiplash injury, defined as bony and soft tissue injuries of the neck caused by rapid acceleration immediately followed by rapid deceleration of the neck and head (1), almost invariably occurring as a consequence of a motor vehicle collision (MVC). With annual North American incidence rates estimated to be between 70 and 329 per 100,000 people $(1,2)$, whiplash injuries are the most common injury following an MVC $(2,3)$. Although it is widely believed that the majority of whiplash patients recover naturally within a few months of their injury, recent research (4) suggests that recovery is often prolonged, with approximately $50 \%$ of patients still complaining of neck pain one year after injury. Moreover, WAD is associated with significant economic costs as a result of lost work productivity, medical care, legal services and other disability-related expenses $(5,6)$. Given the scope and cost of WAD, the identification of effective therapies for patients with whiplash-related injuries, especially chronic WAD, is of obvious importance.

In 1995, the Quebec Task Force (QTF) published its benchmark review (1) of the scientific literature and expert opinion on WAD. One of the primary conclusions of the report was that the majority of therapeutic interventions used in the treatment of WAD had undergone little to no scientific investigation. Accordingly, the QTF emphasized the need for more and higher quality research. More recently, Conlin et al $(7,8)$ conducted a systematic review of the whiplash treatment literature (including studies published from 1993 to 2003) and noted that despite the QTF's recommendations, "remarkably little quality research" (8) had been published in the area of WAD management.

The objective of the present review is to update and expand on previous work by evaluating the strength of evidence for therapies initiated during the acute (less than two weeks), subacute (two to 12 weeks) and chronic (more than 12 weeks) stages of WAD. Treatments were grouped according to time from injury to assist clinicians in deciding on an appropriate treatment course because therapies that are effective in the treatment of acute and subacute WAD may not necessarily be effective when initiated during the chronic phase. Furthermore, treatments for chronic WAD were divided into two sections: noninvasive interventions, and surgical and injection-based interventions. The present article, the fifth in a five-part series, evaluates the evidence for surgical and injection-based interventions initiated during the chronic phase of WAD.

\section{METHOD}

The following is a brief summary of the methods used for the present review. A more detailed explanation of the methodology is provided in the first article of the present series (9). A multistage screening process was conducted to identify all literature that evaluated therapeutic interventions for WAD published from January 1980 to March 2009, regardless of study design. Multiple databases were searched (including MEDLINE, CINAHL, EMBASE, PsycINFO, Web of Science and the Cochrane Central Register of Controlled Trials [CENTRAL]) using the following search terms: whiplash AND (therapy OR treatment OR intervention OR rehabilitation OR surgery OR neurotomy). The literature search was limited to clinical studies written in English that examined adult (18 years of age and older) human populations. A study was deemed eligible for review if it met the following criteria established a priori:

- The purpose of the study was to evaluate the effects of one or more clearly defined treatment protocols for WAD (eg, 'physiotherapy' without further elaboration was not considered to be a clearly defined protocol).

- At least $60 \%$ of the participants in the study sample must have experienced a whiplash injury resulting from an MVC; alternatively, the sample must have included a distinct and separately analyzed subgroup of MVC-related whiplash patients.

- Evaluation of the treatment effect must have involved measurable outcomes.

- Sample included at least three participants with a whiplash injury.

In total, the search procedure yielded 969 citations, 387 of which were duplicates. On screening titles and abstracts for relevance, 121 articles were considered for full review and, after applying inclusion criteria, 83 articles were selected for full review. Information abstracted from studies that met inclusion criteria was organized into tables; studies were grouped according to the type of intervention. For the present article, only studies examining surgical or injection-based interventions initiated during the chronic stage (ie, more than three months postinjury) were included.

All of the included randomized controlled trials (RCTs) were evaluated for methodological quality using a standardized rating scale, the Physiotherapy Evidence Database (PEDro) scale. This evaluation tool was designed specifically for assessing physical therapy research and has been validated for the assessment of RCTs (10). The PEDro scale consists of 10 equally weighted yes/no questions relating to issues of methodological quality and can be accessed at www.pedro. org.au/english/downloads/pedro-scale/. Two independent raters reviewed each article and discrepancies were resolved through consensus or, when that was not possible, by a third rater. Studies with PEDro scores of 9 to 10 were considered to be of 'excellent' methodological quality, while scores of 6 to 8 were considered to be of 'good' quality, and scores of 4 to 5 were considered to be of 'fair' quality. Studies scoring below 4 were judged to be of 'poor' quality and were considered to be methodologically equivalent to non-RCTs for the purpose of formulating conclusions. These descriptive terms of quality assessment were used to simplify the interpretation of results; however, it is important to note that these terms are only intended to provide an indication of a study's rating on the PEDro scale. Non-RCTs were not assigned a PEDro score and were instead given a 'no score' designation.

Due to the limited number of studies investigating each of the specific WAD interventions, it was decided that both meta-analytical and levels-of-evidence approaches would be inappropriate. Therefore, a narrative approach was used to summarize the findings and formulate conclusions.

Because studies employing a nonexperimental or uncontrolled design are generally considered to be of inferior quality, these types of studies were only used to formulate conclusions in the absence of RCTs or when the results of 
TABLE 1

Physiotherapy Evidence Database (PEDro) scores for randomized controlled trials evaluating surgical or injection-based therapies for chronic whiplash-associated disorder

\begin{tabular}{|c|c|c|c|c|c|c|c|c|c|c|c|}
\hline \multirow[b]{2}{*}{ Reference, year } & \multicolumn{10}{|c|}{ PEDro criteria } & \multirow[b]{2}{*}{ Total score } \\
\hline & RA & CA & BS & SB & TB & $A B$ & AF & ITT & BC & PVM & \\
\hline Braker et al (15), 2008 & $\checkmark$ & $\checkmark$ & $\checkmark$ & $\checkmark$ & $\checkmark$ & $\checkmark$ & $\checkmark$ & & $\checkmark$ & $\checkmark$ & 9 \\
\hline Padberg et al (16), 2007 & $\checkmark$ & $\checkmark$ & $\checkmark$ & $\checkmark$ & $\checkmark$ & $\checkmark$ & $\checkmark$ & & $\checkmark$ & $\checkmark$ & 9 \\
\hline Lord et al (27), 1996 & $\checkmark$ & $\checkmark$ & $\checkmark$ & $\checkmark$ & $\checkmark$ & $\checkmark$ & $\checkmark$ & & $\checkmark$ & & 8 \\
\hline Freund and Schwartz (13), 2000 & $\checkmark$ & & $\checkmark$ & $\checkmark$ & $\checkmark$ & & $\checkmark$ & & $\checkmark$ & $\checkmark$ & 7 \\
\hline Barnsley et al (19), 1994 & $\checkmark$ & & $\checkmark$ & $\checkmark$ & $\checkmark$ & $\checkmark$ & $\checkmark$ & & $\checkmark$ & & 7 \\
\hline Byrn et al (12), 1993 & $\checkmark$ & $\checkmark$ & $\checkmark$ & $\checkmark$ & & & $\checkmark$ & & $\checkmark$ & & 6 \\
\hline
\end{tabular}

AB Assessor blinding; AF Adequate follow-up; BC Between-group comparisons; BS Baseline similarity; CA Concealed allocation; ITT Intention-to-treat analysis; PVM Point estimates and variability reported; RA Random allocation; SB Subject blinding; TB Therapist blinding

\section{TABLE 2}

Summary of studies evaluating sterile water trigger point injections for chronic whiplash-associated disorder

\begin{tabular}{ll}
$\begin{array}{l}\text { Reference, year, } \\
\text { country, score }\end{array}$ & Population and methods \\
\hline $\begin{array}{l}\text { Byrn et al (12), } \\
\text { 1993, Sweden, } \\
\text { PEDro score = } 6\end{array}$ & $\begin{array}{l}\text { Randomized contolled trial. } 40 \text { patients with } \\
\text { whiplash-induced neck pain and impaired cervical } \\
\text { range of motion of } 4-6 \text { years that was refractory to } \\
\text { analgesics and physiotherapy were randomly } \\
\text { assigned to receive } 0.3-0.5 \mathrm{~mL} \text { subcutaneous } \\
\text { injections of either sterile water or saline in each } \\
\text { tender trigger point (range 5-80 injections per } \\
\text { patient). Each patient received up to } 3 \text { treatments } \\
\text { during the first } 2 \text { months of the protocol }\end{array}$
\end{tabular}

Byrn et al (11), 1991, Sweden, no score

\author{
Case series. 10 patients with $\geq 6$ months whiplash- \\ related neck pain and impaired cervical range of \\ motion were included following a failed course of \\ analgesics and physiotherapy. All tender trigger \\ points received a $0.1 \mathrm{~mL}$ intracutaneous injection of \\ sterile water, and patients were encouraged to \\ intensify their physiotherapy treatment. The \\ procedure was repeated in patients whose pain \\ recurred
}

\section{Outcome measures}

Pain intensity (VAS), mobility of the

cervical spine (Myrin goniometer), personality (the Neuroticism,

Extroversion and Openness to

experience [NEO] personality

inventory) and psychological

symptoms (Beck Depression

Inventory, Spielberger Anxiety Test

and Mood Adjective Checklist) were

assessed immediately pre- and post-treatment, and at 1, 3 and

8 months after the first treatment

Pain intensity (VAS) was assessed before the first injection and at unspecified intervals over the following 2 months
Results

Patients in the sterile water group reported significantly less mean pain (0.8 versus 2.0 , $\mathrm{P}<0.05)$ and greater cervical mobility $\left(54^{\circ}\right.$ versus $23^{\circ}, \mathrm{P}<0.05$ ) immediately postinjection than those in the saline group; these differences remained significant at the 8-month follow-up ( 2.4 versus 4.7, $\mathrm{P}<0.001$; and $20^{\circ}$ versus $-11^{\circ}$, $\mathrm{P}<0.05$, for pain and mobility, respectively). No between-group differences in personality or psychological symptoms were reported

8 patients were pain free (VAS $=0$ ) and 2 experienced minimal pain (VAS $=2$ ) immediately following the first injection. Nine of the patients were pain free at the end of the follow-up period, 3 of them after a single treatment, while 6 required 2 to 4 treatments. Significance values were not reported

PEDro Physiotherapy Evidence Database; VAS Visual analogue scale

RCTs were conflicting. In addition, when the results of RCTs were conflicting, studies with higher PEDro scores were weighted more heavily.

\section{RESULTS}

Six RCTs (plus two follow-up studies) and 17 non-RCTs were identified that evaluated surgical or injection-based interventions for chronic WAD (ie, more than three months postinjury), and met the inclusion criteria. The mean PEDro score of the RCTs was 7.5, with scores ranging from 6 to 9 (Table 1). Overall, these RCTs were of high methodological quality, with the only common limitation being failure to conduct analyses on an intention-to-treat basis.

\section{Injection-based interventions}

Sterile water injections: Two studies conducted by Byrn et al $(11,12)$ examined the use of sterile water injections in the treatment of chronic WAD (Table 2). In a pilot case series, Byrn et al (11) treated 10 patients with $0.1 \mathrm{~mL}$ intracutaneous sterile water injections into multiple (15 to 25 ) trigger points.
Two months following the initial injections, nine patients reported being completely pain free, although six of these patients received two to four treatments. In a subsequent RCT of good quality, Byrn et al (12) randomly assigned 40 patients to receive subcutaneous injections of $0.3 \mathrm{~mL}$ to $0.5 \mathrm{~mL}$ of either sterile water or saline into multiple (five to 80 ) trigger/ tender points. At eight-month follow-up, the authors found that both pain intensity and mobility of the cervical spine improved significantly more for those in the sterile water group than for those in the saline group. Although these results are promising, there are several methodological issues. While this study had a double-blinded design, blinding may not have been successful due to the painful sensation associated with sterile water but not saline injections. Moreover, saline injections may not have been an effective control because patients receiving this treatment reported greater pain intensity at three and eight months compared with baseline. Finally, because mobility at baseline was not reported, it is not clear whether range of motion (ROM) significantly differed between the two groups before the intervention. 
TABLE 3

Summary of studies evaluating botulinum toxin A (BTXA) trigger point injections for chronic whiplash-associated disorder (WAD)

\begin{tabular}{|c|c|}
\hline $\begin{array}{l}\text { Reference, year, } \\
\text { country, score }\end{array}$ & Population and methods \\
\hline $\begin{array}{l}\text { Braker et al (15), } \\
\text { 2008, Israel, } \\
\text { PEDro score = } 9\end{array}$ & $\begin{array}{l}\text { Randomized controlled trial. } 20 \text { patients with } \\
\text { cervical myofascial pain, } 2-48 \text { weeks after a } \\
\text { whiplash injury, were randomly assigned to } \\
\text { receive either } 200 \text { units of BTXA or placebo } \\
\text { (injected equally into four trigger points) }\end{array}$ \\
\hline
\end{tabular}

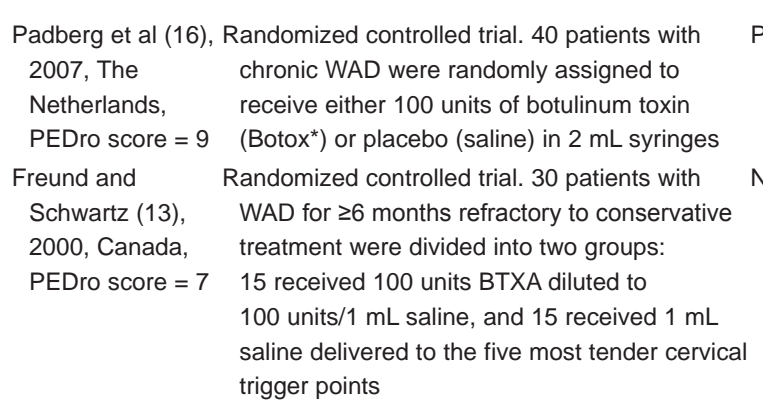

Juan (14), 2003, Case series. 31 patients with WAD for

Spain, no score $\quad \geq 3$ months were included after a failed course of conservative treatment. A dose of 50 to 75 units of BTXA diluted to 100 units $/ 1 \mathrm{~mL}$ saline was injected into each patient's tender superficial muscles. Patients also received information on home exercise
Outcome measures Results

Pain intensity (VAS and verbal rating scale), Although the BTXA group consistently made quality of life (Short-Form 36 Health larger improvements, between-group Survey), cervical ROM and intensity of tender pain-evoked mechanical pressure pain (using an algometer) were assessed at 3, 6, 9, 12 and 24 weeks after injection. A global assessment of treatment efficacy was also rated by physicians at 24 weeks

Pain intensity (VAS) and cervical ROM were After 12 weeks, no significant differences were assessed at baseline and at 12-week follow-up

Neck, head and shoulder pain intensity (VAS), cervical ROM, and the Vernon-Mior Function Index were assessed at baseline and at 2 and 4 weeks post-treatment

Neck pain intensity (VAS), cervical ROM and the Neck Pain Disability Index were assessed initially, and at 1, 4 and 8 weeks after injection differences were nonsignificant with the exception that a greater percentage of patients in the BTXA group achieved a 50\% reduction in pain intensity at 24 weeks ( $70 \%$ versus $11 \%$, $\mathrm{P}<0.05)$

After 12 weeks, no significant differt
found between the two groups

At 4 weeks, patients in the treatment group had better cervical ROM $\left(343 \pm 17.8^{\circ}\right.$ versus $\left.308 \pm 12.9^{\circ}, P<0.01\right)$, and less neck, head and shoulder pain $(10 \pm 1.3$ versus $14.1 \pm 21, P<0.01)$ than those in the placebo group. Although not significant, a greater percentage of patients in the treatment group showed improvement in subjective function (20\% versus $8 \%$ )

In total, $77.4 \%$ of patients responded positively to the treatment. Significant improvements were seen in terms of both pain intensity (from $6.6 \pm 2.1$ to $4.8 \pm 2.1, P<0.05)$ and cervical ROM $(P<0.05)$. Although not significant, neck pain disability also trended toward improvement

*Allergan Inc, USA. PEDro Physiotherapy Evidence Database; ROM Range of motion; VAS Visual analogue scale

Conclusions regarding sterile water injections in chronic WAD: Although there is evidence that sterile water injections are more effective than saline injections, methodological concerns prohibit definitive support for sterile water injections as beneficial for reducing whiplash-related symptoms.

Botulinum toxin A injections: Three RCTs and one nonRCT examined the use of botulinum toxin A (BTXA) injections in the treatment of chronic WAD (Table 3). In an RCT of good quality, Freund and Schwartz (13) randomly assigned 30 patients to receive either 100 units of BTXA or saline injected into five trigger points. Patients in the BTXA group experienced significant reductions in pain intensity four weeks after the treatment, while those in the placebo group showed no such improvement. Similarly, Juan (14) followed 31 patients treated with 50 to 75 units of BTXA and found that pain and ROM improved significantly. In contrast, two RCTs of excellent quality $(15,16)$ compared the effectiveness of BTXA with saline injections and found that BTXA was no more effective than placebo in reducing pain intensity at three and six months following treatment, respectively. However, it is noteworthy that while Padberg et al (16) did not find a trend in favour of the treatment group, Braker et al (15) found that those treated with BTXA reported consistently better outcomes than those in the placebo group, a trend that did not reach significance. Braker et al (15) injected 200 units of BTXA while Padberg et al (16) only injected 100 units, implying that higher doses may be required (although Juan [14] suggested otherwise). In addition, Braker et al (15) actively sought to reduce the time from injury to treatment, with an unreported number of patients receiving treatment during the subacute phase of WAD. Although this suggests that earlier treatment may have some benefit, findings from the subacute WAD literature have not confirmed this postulation $(17,18)$.

Conclusions regarding BTXA injections in chronic WAD: There is contradictory evidence regarding the effectiveness of BTXA injections during the chronic stage of WAD.

Corticosteroid injections: One RCT and three non-RCTs evaluated the effectiveness of corticosteroid injections in the treatment of chronic WAD (Table 4). In a triple-blinded RCT of good quality, Barnsley et al (19) randomly assigned patients to receive intra-articular facet joint injections of either a corticosteroid (5.7 mg betamethasone) or an anesthetic $(0.5 \%$ bupivacaine). The authors found no significant betweengroup differences, with a median time to return of $50 \%$ preinjection pain levels of only three and 3.5 days for those in the corticosteroid group and the anesthetic group, respectively. In contrast, in one of two retrospective case series $(20,21)$, Slipman et al (21) reported that, in a retrospective sample of 18 WAD patients with persistent daily headaches, intraarticular injections of a corticosteroid $(0.8 \mathrm{~mL}$ Celestone Soluspan [betamethasone; Schering-Plough, USA] and $0.2 \mathrm{~mL}$ of $1 \%$ Xylocaine [lidocaine; AstraZeneca UK Ltd]) reduced the frequency of headaches in $61 \%$ of patients, although statistical significance was not reported. 
TABLE 4

Summary of studies evaluating steroid and local anesthetic injections for chronic whiplash-associated disorder

\begin{tabular}{|c|c|}
\hline $\begin{array}{l}\text { Reference, year, } \\
\text { country, score }\end{array}$ & Population and methods \\
\hline $\begin{array}{c}\text { Barnsley et al (19), } \\
\text { 1994, Australia, } \\
\text { PEDro score }=7\end{array}$ & $\begin{array}{l}\text { Randomized controlled trial. } 41 \text { patients with } \\
\geq 3 \text { months whiplash-induced pain in } 1 \text { or more } \\
\text { cervical zygapophysial joints were randomly assigned } \\
\text { to receive } 1 \mathrm{~mL} \text { intra-articular injections of } \\
\text { bupivacaine }(0.5 \%) \text { or betamethasone }(5.7 \mathrm{mg})\end{array}$ \\
\hline $\begin{array}{l}\text { Chauhan et al (22), } \\
\text { 2003, England, ns }\end{array}$ & $\begin{array}{l}\text { Case series. } 43 \text { patients with } \geq 6 \text { months } \\
\text { whiplash-induced shoulder pain (due to impingement) } \\
\text { were included. Patients received a } 40 \text { mg injection of } \\
\text { Depo-Medrone* (methylprednisolone acetate) into the } \\
\text { subacromial space, and underwent } 12 \text { weeks of } \\
\text { physiotherapy to strengthen rotator cuff muscles and } \\
\text { restore shoulder movement }\end{array}$ \\
\hline
\end{tabular}

Slipman et al (20), 2001, USA, ns

Slipman et al (21), 2001, USA, ns

\begin{tabular}{|c|c|}
\hline Outcome measures & Results \\
\hline $\begin{array}{l}\text { Time to } 50 \% \text { return of } \\
\text { preinjection pain was } \\
\text { established through regular } \\
\text { telephone contact and clinic } \\
\text { visits at } 2 \text { and } 12 \text { weeks } \\
\text { postinjection }\end{array}$ & $\begin{array}{l}\text { Median time to a return of } 50 \% \text { preinjection pain } \\
\text { was } 3 \text { days in the steroid group compared with } \\
3.5 \text { days in the local anesthetic group. Duration of } \\
\text { pain relief did not differ between groups }\end{array}$ \\
\hline $\begin{array}{l}\text { Abolition of pain and return of } \\
\text { full range of shoulder } \\
\text { movement were determined } \\
\text { by physical examination at } \\
12 \text { weeks }\end{array}$ & $\begin{array}{l}56 \% \text { of patients had no pain and full movement at } \\
\text { follow-up while } 23 \% \text { had some residual } \\
\text { discomfort, but full movement. } 21 \% \text { of patients still } \\
\text { had significant pain and abnormal movement. } \\
\text { Significance levels were not reported }\end{array}$ \\
\hline $\begin{array}{l}\text { Pain intensity (VAS), work } \\
\text { status, medication usage, } \\
\text { and Oswestry Disability } \\
\text { Index scores were recorded } \\
\text { initially and during a } \\
\text { telephone interview at a } \\
\text { mean of } 33.3 \text { weeks (range } \\
4 \text { to } 65 \text { weeks) after the final } \\
\text { therapeutic injection }\end{array}$ & $\begin{array}{l}\text { At follow-up, the mean Oswestry Disability Index } \\
\text { score was reduced by } 1.6 \% \text { while the mean VAS } \\
\text { pain intensity was reduced by } 29.1 \% \text {. Neither } \\
\text { work status nor medication usage changed } \\
\text { significantly from baseline. Significance levels } \\
\text { were not reported }\end{array}$ \\
\hline $\begin{array}{l}\text { Symptomatic improvement } \\
\text { with respect to headache } \\
\text { frequency, pain (VAS), } \\
\text { employment status and } \\
\text { medication use were } \\
\text { recorded at an average of } \\
19 \text { months post-treatment } \\
\text { (range } 12 \text { to } 29 \text { months) }\end{array}$ & $\begin{array}{l}\text { All patients demonstrated a positive response to } \\
\text { therapeutic intra-articular injections and only } 17 \% \\
\text { failed to experience improvement in terms of } \\
\text { symptomatic headache frequency. Furthermore, } \\
\text { mean pain intensity decreased by } 27 \% \text { while the } \\
\text { percentage of patients employed full time } \\
\text { increased from } 17 \% \text { to } 56 \% \text {. Unfortunately, } \\
\text { statistical significance was not reported }\end{array}$ \\
\hline
\end{tabular}

Case series. 22 patients with $\geq 6$ weeks whiplash-induced cervical radicular pain that had been refractory to conservative treatment were included. Following positive responses to diagnostic cervical nerve root blocks, therapeutic blocks were performed at each affected level on at least 2 occasions. Therapeutic injections of a mixture of $0.8 \mathrm{~mL}$ Celestone Soluspan ${ }^{\dagger}$ and $0.2 \mathrm{~mL}$ of $1 \%$ Xylocaine ${ }^{\ddagger}$ were administered, in addition to physical therapy

Case series. 18 patients with chronic daily headaches secondary to whiplash and refractory to at least a 3-month course of nonsurgical management were included. Patients received injections of a mixture of $0.8 \mathrm{~mL}$ Celestone Soluspan ${ }^{\dagger}$ and $0.2 \mathrm{~mL}$ of $1 \%$ Xylocaine $^{\ddagger}$
*Pfizer Inc, USA; ' Betamethasone; Schering-Plough, USA; ${ }^{\ddagger}$ Lidocaine; AstraZeneca UK Ltd. ns No score; PEDro Physiotherapy Evidence Database; VAS Visual analogue scale

In another retrospective case series, Slipman et al (20) reported on 22 patients who underwent fluoroscopically guided cervical selective nerve root blocks using the same corticosteroid solution. Patients received an average of 2.1 injections and treatment was administered in conjunction with a physiotherapy program. Although $59 \%$ of patients experienced a transient steroid effect following treatment, there were no measurable benefits associated with this treatment at follow-up (an average of 33 weeks post-treatment).

Finally, in a case series involving 43 WAD patients with both a positive impingement sign and a positive analgesic block response of a painful shoulder, Chauhan et al (22) evaluated the effectiveness of subacromial space corticosteroid (40 mg Depo-Medrone [methylprednisolone acetate; Pfizer Inc, USA]) injections. In addition to the injection, patients also participated in a 12 -week physiotherapy program designed to correct scapulothoracic rhythmic dysfunction and strengthen the rotator cuff muscles. The authors reported that $79 \%$ of patients showed 'significant' or 'moderate' shoulder pain relief. However, it was not clear whether the steroid injection, the physiotherapy or the combination of the two interventions were responsible for this improvement. Moreover, given that the authors failed to report several pertinent details (including statistical significance and the assessment procedure), the overall value of this study is limited.
Conclusions regarding corticosteroid injections in chronic WAD: Corticosteroid intra-articular and selective nerve root block injections did not appear to be effective for relieving pain in patients with chronic WAD. Based on the results of a case series (22), subacromial space corticosteroid injections combined with physiotherapy may be effective for patients with late-onset shoulder pain; however, further research is needed.

Tropisetron trigger point injections: One case series examined the effect of tropisetron, a 5HT3 receptor antagonist, in patients with chronic WAD (Table 5). Ettlin (23) followed 20 patients who received a total of 73 sessions of trigger point injections. In $84 \%$ of the sessions, pain relief of greater than $50 \%$ was achieved, with the duration of relief lasting more than two weeks in $52 \%$ of the sessions and more than two months in $10 \%$ of the sessions. It should be noted, however, that the duration of relief following treatment was highly variable, both within and between individuals. Furthermore, because this study was not blinded and failed to include a control group, it is difficult to assess the true benefit of tropisetron.

Conclusions regarding tropisetron trigger point injections in chronic WAD: Although one case series reported that tropisetron injections temporarily relieved whiplash-related pain, the evidence is not strong enough to demonstrate the effectiveness of this treatment. 
TABLE 5

Summary of a study evaluating tropisetron local trigger point injections for chronic whiplash-associated disorder

\begin{tabular}{|c|c|c|c|}
\hline $\begin{array}{l}\text { Reference, year, } \\
\text { country, score }\end{array}$ & Population and methods & Outcome measures & Results \\
\hline $\begin{array}{l}\text { Ettlin (23), 2004, } \\
\text { Switzerland, } \\
\text { no score }\end{array}$ & $\begin{array}{l}\text { Case series. } 20 \text { patients with } \geq 6 \text { months of whiplash-related head, } \\
\text { neck and shoulder pain received a maximum of } 5 \text { injections of } \\
\text { tropisetron (an antiemetic serotonin receptor blocker), } 0.5 \mathrm{~mL} \text { to } \\
1.0 \mathrm{~mL} \text { per trigger point. Subsequent injections were administered } \\
1 \text { week after a renewed increase in pain. A mean of } 15 \text { trigger } \\
\text { points were injected per session }\end{array}$ & $\begin{array}{l}\text { Subjective pain relief of } \\
\text { greater than } 50 \% \text { and } \\
\text { duration of pain relief } \\
\text { were recorded for an } \\
\text { unspecified follow-up } \\
\text { period }\end{array}$ & $\begin{array}{l}\text { Pain relief of greater than } 50 \% \text { was } \\
\text { achieved in } 84 \% \text { of the } 73 \text { treatment } \\
\text { sessions. For } 52 \% \text { of the sessions, the } \\
\text { pain relief lasted more than } 2 \text { weeks, and } \\
\text { in } 10 \% \text { the pain relief lasted more than } \\
2 \text { months }\end{array}$ \\
\hline
\end{tabular}

TABLE 6

Summary of a study evaluating dextrose and lidocaine intra-articular injections for chronic whiplash-associated disorder

\begin{tabular}{llll}
\hline $\begin{array}{l}\text { Reference, year, } \\
\text { country, score }\end{array}$ & Population and methods & Outcome measures & Results \\
\hline Hooper et al (24), & Case series. 18 patients with chronic whiplash- & The Neck Disability Index was completed & Mean Neck Disability Index scores \\
2007, Canada, & associated disorder were included. 15 patients & at baseline and at 2, 6 and 12 months & were significantly improved at each of \\
no score & completed the intra-articular prolotherapy treatment & following treatment & the follow-up sessions, with a \\
& $(0.5 \mathrm{~mL}$ to $1.0 \mathrm{~mL}$ of 20\% dextrose solution was & & reduction from 24.71 at baseline to \\
& $\begin{array}{l}\text { injected into each zygapophysial joint using 25-gauge } \\
\text { spinal needles and fluoroscopic guidance })\end{array}$ & 10.94 at the 12-month follow-up \\
& & $(\mathrm{P}<0.001)$
\end{tabular}

TABLE 7

Summary of a study evaluating epidural blood patch (EBP) therapy for chronic whiplash-associated disorder (WAD)

\begin{tabular}{|c|c|c|c|}
\hline $\begin{array}{l}\text { Reference, year, } \\
\text { country, score }\end{array}$ & Population and methods & Outcome measures & Results \\
\hline $\begin{array}{l}\text { Ishikawa et al } \\
\text { (25), } 2007 \text {, } \\
\text { Japan, no } \\
\text { score }\end{array}$ & $\begin{array}{l}\text { Case series. } 66 \text { patients with chronic WAD underwent } \\
\text { radioisotope cisternography to determine which patients } \\
\text { also had a CSF leak. Of } 37 \text { patients identified as having } \\
\text { both WAD and a CSF leak, } 36 \text { received EBP treatment }\end{array}$ & $\begin{array}{l}\text { Assessed at baseline, } 1 \text { week and } \\
6 \text { months, outcomes included } \\
\text { presence of WAD/CSF leak symptoms } \\
\text { (headache, loss of memory, dizziness, } \\
\text { visual impairment, neck pain and } \\
\text { nausea) and work status }\end{array}$ & $\begin{array}{l}\text { The percentage of patients who reported } \\
\text { the presence of symptoms decreased } \\
\text { significantly following EBP therapy and at } \\
\text { both the 1-week }(P<0.1) \text { and } 6 \text {-month } \\
\text { follow-up }(P<0.1) \text {. Work status was also } \\
\text { significantly improved after EBP therapy } \\
\text { for } 89 \% \text { of patients }\end{array}$ \\
\hline
\end{tabular}

CSF Cerebrospinal fluid

Dextrose and lidocaine intra-articular injections: One case series examined the use of 'joint regeneration' therapy (theorized to strengthen the zygapophysial joint capsule) during the chronic phase of WAD (Table 6). Hooper et al (24) administered intra-articular injections of dextrose and lidocaine to 18 patients and found that pain and disability improved significantly at two-, six- and 12-month follow-up. However, because this study was unblinded, failed to include a control group and permitted patients to participate in cointerventions (during and after the treatment), it is not clear whether the observed improvement could be attributed to the experimental treatment.

Conclusions regarding dextrose and lidocaine intra-articular injection therapy in chronic WAD: Although the results of one small case series suggested that 'joint regeneration' (dextrose and lidocaine intra-articular) therapy may reduce whiplash-related pain and disability, the evidence is not strong enough to establish the effectiveness of this treatment.

Epidural blood patch therapy

An intriguing case series (25) examined the effectiveness of epidural blood patch (EBP) therapy in patients with chronic WAD and a suspected cerebrospinal fluid (CSF) leak
(Table 7). Ishikawa et al (25) assessed 66 chronic WAD patients with a suspected CSF leak and found evidence of a CSF leak in 37 patients. Following a two-week 'control' period in which patients participated in conventional therapies, 36 patients received the experimental therapy (EBP), which was repeated up to three times if symptoms did not improve (with a mean of 2.2 procedures). The authors reported that, while no symptom improvement was noted during the control period, pretreatment symptoms (headache, memory, dizziness, visual impairment, cervical pain, nausea and auditory symptoms) were significantly reduced one week following treatment. Furthermore, these improvements were maintained for up to six months. Although the authors concluded that their findings implicated a CSF leak in the etiology of chronic WAD, there is no way of knowing if this was, in fact, the case. To our knowledge, a consistent relationship between whiplash injuries and CSF leaks has yet to be established and, hence, interpretation of this study is difficult.

Conclusions regarding EBP therapy in chronic WAD: While the results of one case series (25) suggested that EBP therapy may be an effective treatment for chronic WAD involving a suspected CSF leak, the association of a CSF leak with chronic WAD has never been established. 


\section{Surgical interventions}

Radiofrequency neurotomy: One RCT of good methodological quality, two follow-up studies and five non-RCTs examined the use of radiofrequency neurotomy (RFN) in the treatment of chronic WAD (Table 8). Following a successful pilot project in which $70 \%$ of those who underwent lower cervical medial branch neurotomies achieved complete pain relief for at least six months (26), Lord et al (27) randomly assigned 24 patients (selected on the basis of response to placebocontrolled diagnostic blocks) to undergo either active or sham radiofrequency procedures. Twenty-seven weeks following surgery, seven patients (58\%) in the active group reported being pain free, compared with only one patient $(8 \%)$ in the control group. Furthermore, the median time to the return to $50 \%$ of the preoperative level of pain was found to be significantly greater for patients in the active group (263 days) than for patients in the control group (8 days). Interestingly, patients who reported complete pain relief also exhibited resolution of preoperative psychological distress, as measured by the Symptom Checklist 90-R (28). Finally, in a follow-up of patients included in both the pilot project and the RCT $(26,27)$, McDonald et al (29) reported on 28 patients who underwent lower cervical medial branch neurotomies, 18 of whom obtained complete pain relief for at least 90 days; the median duration of relief for these patients was 421 days. It should be noted that Lord et al (26) performed 10 third occipital neurotomies for the treatment of $\mathrm{C} 2$ to $\mathrm{C} 3$ zygapophysial joint pain during their pilot project and found that the rate of technical failure was considerably higher for this procedure, with only three of 10 patients achieving longlasting pain relief. Consequently, Lord et al recommended that RFN should not be used to treat $\mathrm{C} 2$ to $\mathrm{C} 3$ zygapophysial joint pain until technical difficulties (such as inadequate coagulation) are resolved.

While these results suggest that RFN is an effective treatment for chronic whiplash, a number of methodological concerns have been noted (30). First, there is some indication that blinding may have been compromised in that $42 \%$ of patients in the active treatment group developed complications (lasting pain and/or numbness) following surgery, which may have revealed the treatment assignment. Second, significantly more patients in the control group reported being involved in injury-related litigation at baseline than patients in the experimental group (83\% versus 33\%, respectively). Although this may have biased results in favour of the treatment group, there is some evidence that litigants and nonlitigants do not differ significantly in terms of success, duration of relief or satisfaction with RFN procedures (27,31). Despite these criticisms, the study by Lord et al (27) is considered to be a breakthrough in the treatment of chronic WAD and received a PEDro score of 8 , indicating high methodological quality.

Investigating the effect of repeated RFN, Husted et al (32) identified 21 patients who underwent multiple (two to seven) RFNs and found that the rate of success and the duration of relief were consistent following each procedure - in total, 39 of 41 surgeries were successful, with a mean duration of relief of 11.5 months. It should be noted, however, that this study involved a self-selected group of patients who were satisfied with their initial treatment and who had decided to repeat the procedure, raising the possibility of placebo effects. In another case series involving 40 patients, Prushansky et al (33) investigated the effect of RFN using a large number of outcomes and reported that, in addition to reductions in pain intensity, treatment with RFN was associated with improvement in pain-related disability, cervical ROM, isometric cervical muscle strength and cervical pressure pain threshold; however, $30 \%$ of the study's participants were excluded because they were lost to follow-up. Finally, in a case series involving 14 patients, Liliang et al (34) examined the effectiveness of pulsed radiofrequency lesioning. By using multiple cycles at lower temperatures, this technique does not cause thermal tissue damage to adjacent nerve roots and is virtually painless. The authors reported $86 \%$ of patients at one-month follow-up and $64 \%$ of patients at one-year follow-up experienced significant pain relief.

Conclusions regarding RFN for chronic WAD: Although relief may not be permanent, there is strong evidence that RFN is effective in reducing pain in patients with chronic WAD. Moreover, it appears that the procedure can be repeated with a similar probability of success. Nevertheless, further research is needed to determine which patients are most likely to obtain significant relief from this highly invasive procedure.

Occipital nerve decompression: One case series (35) examined the use of greater occipital nerve decompression to relieve chronic whiplash-related headaches in 13 patients undergoing a total of 18 procedures (Table 9). While none of the patients reported achieving complete pain relief, 13 (72\%) of the operations resulted in greater than $50 \%$ relief for at least three months following the procedure. Unfortunately, this study was not blinded, did not include a control group, did not report statistical significance and used a carefully selected sample of patients. Consequently, it is not clear on the basis of this study whether neurolysis of the greater occipital nerve actually had a beneficial effect on whiplashrelated headache.

Conclusions regarding occipital nerve decompression in chronic WAD: On the basis of one case series (35), there was limited evidence that greater occipital nerve decompression may be effective in reducing whiplash-related headache, although further research using more rigorous methodology is needed before definitive conclusions can be drawn.

Carpal tunnel decompression: One case series evaluated the effectiveness of carpal tunnel decompression in the treatment of chronic whiplash-related neck and shoulder pain (Table 10). The rationale given for this intervention is that entrapment of the brachial plexus and peripheral nerves, including the median nerve at the carpal tunnel, may be a cause of pain following whiplash injury (36). Alpar et al (36) compared 38 WAD patients who underwent carpal tunnel decompression surgery with 30 patients treated as usual. At a mean follow-up time of 18 months, neck and shoulder pain had 'resolved' in $95 \%$ of the surgery patients, but only in $7 \%$ of the controls. However, because this study was not blinded and did not report statistical significance, it is difficult to draw any meaningful conclusions on the basis of this study.

Conclusions regarding carpal tunnel decompression in chronic WAD: Although there was limited evidence that carpal tunnel decompression may be effective in reducing 
TABLE 8

Summary of studies evaluating radiofrequency neurotomy (RFN) for chronic whiplash-associated disorder (WAD)

\begin{tabular}{|c|c|c|c|}
\hline $\begin{array}{l}\text { Reference, year, } \\
\text { country, score }\end{array}$ & Population and methods & Outcome measures & Results \\
\hline $\begin{array}{l}\text { Lord et al (27), } \\
\text { 1996, Australia, } \\
\text { PEDro score = } \\
8\end{array}$ & $\begin{array}{l}\text { Randomized controlled trial. } 24 \text { patients with } \\
\geq 3 \text { months pain in one or more cervical } \\
\text { zygapophysial joints (excluding C2-C3) that was } \\
\text { refractory to conventional therapy were randomly } \\
\text { assigned to one of two treatment groups. } \\
12 \text { patients received percutaneous RFN, and } \\
12 \text { received a sham neurotomy. Patients received }\end{array}$ & $\begin{array}{l}\text { Pain intensity (VAS), the McGill } \\
\text { Pain Questionnaire and yes/no } \\
\text { questions regarding pain during } \\
\text { activities were assessed at } \\
\text { baseline and at a 3-month } \\
\text { follow-up. Time to return of } 50 \% \\
\text { preoperative pain level was also }\end{array}$ & $\begin{array}{l}6 \text { of } 12 \text { control group patients and } 3 \text { of } 12 \text { active } \\
\text { treatment patients experienced return of pain } \\
\text { immediately after the operation. Significantly different } \\
\text { median times elapsed before pain returned to the } 50 \% \\
\text { preoperative level: } 263 \text { days in the active treatment } \\
\text { group compared with } 8 \text { days in the sham treatment } \\
\text { group }(P<0.05)\end{array}$ \\
\hline
\end{tabular}

Husted et al (32), Case series. 22 patients with chronic WAD who

2008, USA, ns had previous success with RFN but whose symptoms had returned were included in this study to receive another RFN treatment. One patient was lost to follow-up

Liliang et al (34), Case series. 14 patients with chronic WAD assessed via telephone contact

Success of treatment was quantified as greater than $50 \%$ relief of pain following the operation

Repeat treatment was considered to be a success in $95 \%$ of patients and a failure in $1 \%$. The mean duration of relief was 11.5 months, which is not significantly different from the duration of relief following initial treatment

Primary outcome measures

12, 11 and 9 patients reported a greater than $60 \%$ 2008, Taiwan, underwent pulsed radiofrequency lesioning of the included pain intensity (VAS) and ns $\quad$ cervical medial branches. The procedures were performed in 2 cycles of $180 \mathrm{~s}$ after localization under fluoroscopy guide medicine requirements. Outcomes were assessed at 1 , 6 and 12 months after the procedure

Prushansky et al Case series. 40 patients with chronic WAD (33), 2006, (whose pain remained after receiving Israel, ns conservative treatments) underwent cervical RFN in various locations
Sapir and Gorup Cohort study. 46 patients with $\geq 5$ months of (31), 2001, whiplash-induced headache, neck pain and USA, ns shoulder pain were referred following a failed course of conservative treatment. 28 patients were litigant while 18 patients were nonlitigant. Al patients had successful diagnostic medial branch nerve blocks before undergoing therapeutic RFN

McDonald et al Follow-up study. This study was a follow-up of (29), 1999, 2 previous studies (Lord et al, 1995 [26] and Australia 1996 [27]). Of the 28 patients who underwent RFN between C3-C4 and C6-C7, 11 were from Lord et al 1995 (26), 14 were from Lord et al 1996 (27) and 3 were new. Most patients received repeat procedures once their pain returned
Pain intensity (VAS), the Neck Disability Index, cervical range of motion, isometric cervical muscle strength, cervical pressure pain threshold, Symptom Checklist 90-R and subjective report of improvement were assessed at baseline and approximately 1 year after the intervention Pain intensity (VAS), medication use and self-reported symptom improvement were obtained at baseline, 2 weeks and 1 year post-treatment

The primary outcome measure was time to return of $50 \%$ preoperative pain level. Pain intensity (VAS) and the McGill Pain Questionnaire were assessed at baseline and at 3- and 12-month follow-ups or when pain returned

Wallis et al (28), Secondary analysis. This study used a subset of Pain intensity (VAS), the McGill
1997, Australia the patients included in Lord et al 1996 (27). Only Pain Questionnaire, the the 17 patients with a single painful joint were retained for analysis. The authors reasoned that any untreated painful joints could negatively influence the patient's psychological profile

Symptom Checklist 90-R and yes/no questions regarding pain during activities were assessed at baseline and at 3 months post-treatment

Lord et al (26), Case series. 19 patients with WAD for $\geq 3$ months The primary outcome measure 1995, Australia, were diagnosed with cervical zygapophysial joint was duration of complete pain ns pain through comparative local anesthetic blocks. 10 patients underwent therapeutic third occipital neurotomy and 10 underwent lower cervical medial branch neurotomy. 28 procedures were performed for treatment of 21 joints relief, defined as absolutely no pain in the targeted region. Progress was recorded at 3 and 12 months follow-ups, or when the pain returned reduction in pain at the 1-, 6- and 12-month follow-ups, respectively. Medicine requirements were also decreased in 13, 12 and 10 patients at the 1-, 6- and 12-month follow-ups, respectively

Compared with baseline, patients showed significant improvement on each of the outcome measures, including pain intensity ( $32 \pm 30$ versus $52 \pm 25)$, neck disability $(17.2 \pm 9.7$ versus $22.5 \pm 9)$ and cervical range of motion (251.3 \pm 68.2 versus $212 \pm 67.5)$, each significant at $\mathrm{P}<0.001$. Collectively, improvement was noted in $70 \%$ of patients at the 1 -year follow-up, with $80 \%$ satisfied with the procedure

Compared with baseline, both litigants and nonlitigants experienced a significant reduction in pain intensity (from $8.2 \pm 1$ to $3.6 \pm 1.8, P<0.05$ ), and had reduced medication use by $50 \%$; however, between-group differences were not significant

Pain refractory to the initial treatment (less than 30 days relief) did not respond to a second treatment. Recurrent pain that was relieved by the initial treatment for at least 90 days was relieved by repeat procedures for at least 90 days: median pain relief per procedure in this group $(n=11)$ was 218.5 days; the range of cumulative duration of relief was 14 months to 5.4 years, as a result of 4 shorter-lasting procedures and 2 longerlasting procedures

6 of 9 patients receiving the active treatment and 3 of 8 receiving the sham neurotomy experienced complete resolution of psychological distress, total pain relief and full restoration of function

3 of 10 patients who underwent third occipital neurotomy and 7 of 10 patients who underwent lower cervical medial branch neurotomy obtained complete pain relief for clinically useful periods ( 6 months to 2 years). Ataxia was a regular side effect of third occipital neurotomy

ns No score; PEDro Physiotherapy Evidence Database; VAS Visual analogue scale 
TABLE 9

Summary of a study evaluating occipital nerve decompression for chronic whiplash-associated disorder

\begin{tabular}{|c|c|c|c|}
\hline $\begin{array}{l}\text { Reference, year, } \\
\text { country, score }\end{array}$ & Population and methods & Outcome measures & Results \\
\hline $\begin{array}{l}\text { Magnusson et al (35), } \\
\text { 1996, Iceland, no score }\end{array}$ & $\begin{array}{l}\text { Case series. } 13 \text { patients with } \geq 6 \text { months of } \\
\text { whiplash-induced pain in the occipital region were } \\
\text { selected from a larger subset of patients. All patients } \\
\text { underwent occipital nerve decompression surgery; } \\
5 \text { received bilateral decompression in separate } \\
\text { procedures }\end{array}$ & $\begin{array}{l}\text { Headache disability, rated on a } \\
\text { numerical scale and based on intensity } \\
\text { and duration, was assessed } \\
\text { preoperatively and at a mean of } \\
28.7 \text { months (range } 12-38 \text { months) } \\
\text { after surgery }\end{array}$ & $\begin{array}{l}7 \text { operations resulted in a more than } 75 \% \\
\text { reduction in headache disability, } \\
6 \text { resulted in a } 50 \% \text { to } 75 \% \text { reduction, } \\
\text { and } 5 \text { resulted in minimal or no relief. } \\
\text { None of the patients attained complete } \\
\text { pain relief }\end{array}$ \\
\hline
\end{tabular}

TABLE 10

Summary of a study evaluating carpal tunnel decompression for chronic whiplash-associated disorder

\begin{tabular}{|c|c|c|c|}
\hline $\begin{array}{l}\text { Reference, year, } \\
\text { country, score }\end{array}$ & Population and methods & Outcome measures & Results \\
\hline $\begin{array}{l}\text { Alpar et al (36), } \\
\text { 2002, United } \\
\text { Kingdom, no } \\
\text { score }\end{array}$ & $\begin{array}{l}\text { Cohort study. } 38 \text { patients with chronic neck, shoulder and arm pain } \\
\text { attributed to whiplash injury and refractive to physiotherapy, } \\
\text { nonsteroidal anti-inflammatory drugs and collar use for 1-3 weeks } \\
\text { underwent surgical decompression of the carpal tunnel. } 30 \text { patients } \\
\text { with similar signs and symptoms served as controls }\end{array}$ & $\begin{array}{l}\text { Pain intensity (visual analogue } \\
\text { scale) was assessed initially and } \\
\text { at a mean follow-up of } 18 \text { months } \\
\text { (range } 12-24 \text { months) }\end{array}$ & $\begin{array}{l}\text { Neck and shoulder pain resolved in } \\
36 \text { patients (95\%) who underwent } \\
\text { surgery, but resolved in only } 2(7 \%) \\
\text { of the controls. Significance levels } \\
\text { were not reported }\end{array}$ \\
\hline
\end{tabular}

TABLE 11

Summary of studies evaluating cervical discectomy and fusion for chronic whiplash-associated disorder

\begin{tabular}{|c|c|c|c|}
\hline $\begin{array}{l}\text { Reference, year, } \\
\text { country, score }\end{array}$ & Population and methods & Outcome measures & Results \\
\hline $\begin{array}{l}\text { Long et al (38), } \\
\text { 2006, USA, } \\
\text { no score }\end{array}$ & $\begin{array}{l}\text { Case series. On the basis of response to } \\
\text { a diagnostic block protocol, } 44 \text { (of } 70 \text { ) } \\
\text { patients were chosen for posterior } \\
\text { cervical fusion of } \mathrm{C} 1, \mathrm{C} 2, \mathrm{C} 3 \text { and } \mathrm{C} 4 \text { in } \\
\text { several combinations }\end{array}$ & $\begin{array}{l}\text { The primary outcome was pain intensity, } \\
\text { which was assessed at baseline, } \\
6 \text { weeks, } 3 \text { and } 6 \text { months, and 1, } 2 \text {, } \\
3 \text { and } 4 \text { years after surgery. Pain was } \\
\text { rated on a } 5 \text {-point scale (where } 1=\text { no } \\
\text { pain and } 5 \text { = excruciating pain) }\end{array}$ & $\begin{array}{l}\text { At baseline, all patients reported severe/excruciating pain. } \\
\text { At } 6 \text { months through } 2 \text { years following surgery, only } \\
3 \text { patients reported pain at this level, while at } 4 \text { years, } \\
5 \text { patients reported pain at this level. At } 4 \text { years } \\
\text { post-treatment, } 88.6 \% \text { of the patients reported satisfactory } \\
\text { pain relief }\end{array}$ \\
\hline $\begin{array}{l}\text { Algers et al (37), } \\
\text { 1993, Sweden, } \\
\text { no score }\end{array}$ & $\begin{array}{l}\text { Case series. } 20 \text { patients with symptoms } \\
\text { of prolonged and severe headache, } \\
\text { disabling neck pain and radicular pain } \\
\text { for at least } 1 \text { year (range } 1 \text { to } 25 \text { years) } \\
\text { following a whiplash injury underwent } \\
\text { anterior cervical discectomy with } \\
\text { interbody fusion }\end{array}$ & $\begin{array}{l}\text { Patients were assessed for pain and } \\
\text { symptoms at a mean of } 4 \text { years } \\
\text { postsurgery (range } 1 \text { to } 8 \text { years): results } \\
\text { were classified as excellent, good, fair } \\
\text { and poor }\end{array}$ & $\begin{array}{l}11 \text { patients noted reduced headaches and neck pain - } \\
6 \text { patients reduced paresthesia, } 3 \text { patients reduced } \\
\text { radicular pain, } 5 \text { improved auditory symptoms, } 4 \text { improved } \\
\text { visual symptoms and } 6 \text { improved vertigo, while vertigo } \\
\text { worsened in } 4\end{array}$ \\
\hline
\end{tabular}

whiplash-related pain, the evidence is insufficient to determine the effectiveness of this procedure.

Cervical discectomy and fusion: Two case series examined the effectiveness of cervical discectomy and fusion for chronic WAD (Table 11). Algers et al (37) followed 20 patients who underwent discectomy and an anterior cervical fusion and reported that results were 'unsatisfying', although $55 \%$ of patients reported at least some reduction in headache and neck pain. Conversely, in a case series involving 44 patients selected on the basis of response to diagnostic blocks, Long et al (38) performed posterior cervical fusion of $\mathrm{C} 1, \mathrm{C} 2, \mathrm{C} 3$ and $\mathrm{C} 4$ in various combinations. Bony fusion was achieved in $95 \%$ of patients, with $79 \%$ obtaining complete pain relief and another $14 \%$ obtaining satisfactory relief. Moreover, pain intensity was reported to be significantly reduced for up to four years, although statistical results were not reported.

Conclusions regarding cervical discectomy and fusion in chronic WAD: Only two low-quality case series $(37,38)$ reported on cervical discectomy and fusion; however, it is not clear whether this procedure provides substantial relief for patients with chronic WAD.

\section{DISCUSSION}

In total, 25 studies were identified that examined surgical and injection-based interventions initiated during the chronic phase of WAD (more than three months). While a few of the included RCTs were of good overall quality, the majority of the studies were small, uncontrolled nonrandomized trials or case series. Moreover, with the exception of research evaluating botulinum toxin injections, none of the interventions were investigated by more than one RCT. This highlights the wide range of surgical and injection-based interventions used to treat chronic WAD, but it also means that many of the conclusions reached in the present review are based on limited evidence and, as such, should be viewed with some caution.

Based on the results of one high-quality RCT and several non-RCTs, there is strong evidence that RFN is effective in reducing whiplash-related pain. Furthermore, the success of 
TABLE 12

Summary of evidence for surgical and injection-based therapies for chronic whiplash-associated disorder (WAD)

Intervention
Sterile water injections
Botulinum toxin injections
Corticosteroid injections

Tropisetron injections

Intra-articular dextrose and lidocaine injections

Epidural blood patch therapy

Radiofrequency neurotomy

Occipital nerve decompression

Carpal tunnel decompression

Cervical discectomy and fusion
Conclusions

Although there is evidence that sterile water injections are more effective than saline injections, methodological concerns prohibit definitive support for sterile water injections as beneficial for reducing whiplash-related symptoms

There is contradictory evidence regarding the effectiveness of botulinum toxin injections during the chronic stage of WAD

Corticosteroid intra-articular and selective nerve root block injections did not appear to be effective for relieving pain in patients with chronic WAD. Based on the results of a case series, subacromial space corticosteroid injections combined with physiotherapy may be effective for patients with late-onset shoulder pain; however, further research is needed

Although one case series reported that tropisetron injections temporarily relieve whiplash-related pain, the evidence is not strong enough to demonstrate the effectiveness of this treatment

Although the results of one small case series suggested that 'joint regeneration' (intra-articular dextrose and lidocaine) therapy may reduce whiplash-related pain and disability, the evidence is not strong enough to establish the effectiveness of this treatment

While the results of one case series suggested that epidural blood patch therapy may be an effective treatment for chronic WAD involving a suspected cerebrospinal fluid leak, the association of a cerebrospinal fluid leak with chronic WAD has never been established

Although relief may not be permanent, there is strong evidence that radiofrequency neurotomy is effective in reducing pain in patients with chronic WAD. Moreover, it appears that the procedure can be repeated with a similar probability of success. Nevertheless, further research is needed to determine which patients are most likely to obtain significant relief from this highly invasive procedure

On the basis of one case series, there was limited evidence that greater occipital nerve decompression may be effective in reducing whiplash-related headache, although further research using more rigorous methodology is needed before definitive conclusions can be drawn

Although there was limited evidence that carpal tunnel decompression may be effective in reducing whiplash-related pain, the evidence was insufficient to determine the effectiveness of this procedure

Only two low-quality case series reported on cervical discectomy and fusion; however, it is not clear whether this procedure provides substantial relief for patients with chronic WAD
RFN in a significant number of chronic WAD patients suggests that the etiology of pain may often be due to cervical facet joint injuries. While this conclusion is consistent with the findings from Conlin et al (8), a more recent review (30) deemed the RCT by Lord et al (27) to be 'scientifically inadmissible'; however, the criteria for dismissing this study appear to be relatively minor and do not justify this extreme position. Nevertheless, RFN has been implemented slowly and with some reluctance, perhaps because clinical experience has not generated sufficient enthusiasm, anticipated benefits do not outweigh potential risks, or the treatment effect, although quite prolonged, is not permanent. Considering the invasive nature of this procedure and some uncertainty regarding which patients will actually benefit, additional research is needed.

Several other treatments were evaluated and supported by single, small, nonrandomized trials, most of which were case series - tropisetron injections, intra-articular dextrose and lidocaine injections, EBP therapy, subacromial and selective nerve root block corticosteroid injections, occipital nerve decompression and carpal tunnel decompression. While some of these trials represent promising innovations in the treatment of chronic WAD, further research is needed to determine the effectiveness of these interventions. There is also evidence that sterile water injections are superior to saline injections, although this evidence does not convincingly demonstrate the effectiveness of sterile water injections in treating whiplash-related symptoms.

There is conflicting evidence regarding the effectiveness of botulinum toxin injections. While only one of three RCTs (13) found that BTXA injections were associated with significant benefit compared with placebo, one of the other trials (15) reported a consistent trend in favour of BTXA over placebo. Additional research is needed to establish the effectiveness of this intervention. Similarly, cervical discectomy and fusion was evaluated in two case series with conflicting results. Furthermore, it does not appear that intra-articular corticosteroid injections are beneficial during the chronic stage of WAD.

The present review was limited by several methodological concerns. First, because of the small number of studies in the whiplash literature, the criteria for inclusion were quite broad. All studies were included regardless of study design, as long as $60 \%$ of the sample experienced a WAD and they included a sample of at least three participants with a whiplash injury. This may have resulted in the inclusion of some studies of lower scientific merit; however, such studies were only used to formulate conclusions in the absence of superior RCTs, and these limitations were noted in the conclusions themselves as well as in the discussion. Second, there are limitations with the quality assessment process used in the current review to evaluate the methodological quality of RCTs. For example, it is possible that an RCT with significant between-group differences at baseline that does not blind patients, therapists or assessors could still have a PEDro score of 6 and be considered a study of good methodological quality despite these significant limitations. Again, these issues were noted in relevant conclusions and study descriptions. Nevertheless, these measures do not negate the need for readers to be 'critical consumers' of the material presented.

Another limitation that should be noted is that conclusions based on the studies included in the present review may not be generalizable to all patients with WAD. Patients who agree to undergo invasive interventions have likely already 
failed to benefit from more conservative treatments and may experience a greater degree of distress from their symptoms than patients who do not seek out such treatments. This may be particularly true of patients who participate in studies investigating surgical procedures - one can assume that they are chronic whiplash patients who are more severely affected.

Due to the cost and risk associated with surgical and injection-based interventions, it is of particular importance that these procedures are rigorously evaluated. The need for high-quality research is highlighted by the fact that such invasive interventions are the most likely to elicit placebo

\section{REFERENCES}

1. Spitzer WO, Skovron ML, Salmi LR et al. Scientific monograph of the Quebec Task Force on whiplash-associated disorders: Redefining "whiplash" and its management. Spine 1995;20:2S-73S.

2. Quinlan KP, Annest JL, Myers B, Ryan G, Hill H. Neck strains and sprains among motor vehicle occupants - United States, 2000. Accid Anal Prev 2004;36:21-7.

3. Berglund A, Alfredsson L, Jensen I, Bodin L, Nygren A. Occupant- and crash-related factors associated with risk of whiplash injury. Ann Epidemiol 2003;13:66-72.

4. Carroll LJ, Holm LW, Hogg-Johnson S, et al. Course and prognostic factors for neck pain in whiplash-associated disorders (WAD): Results of the Bone and Joint Decade 2000-2010 Task Force on Neck Pain and Its Associated Disorders. Spine 2008;33(4 Suppl):S83-92.

5. Yoganandan N, Pintar FA, Kleinberger M. Whiplash injury. Biomechanical experimentation. Spine 1999;24:83-5.

6. Freeman MD, Croft AC, Rossignol AM, Weaver DS, Reiser M. A review and methodologic critique of the literature refuting whiplash syndrome. Spine 1999;24:86-98.

7. Conlin A, Bhogal S, Sequeira K, Teasell R. Treatment of whiplash-associated disorders - part I: Noninvasive interventions. Pain Res Manage 2005;10:21-32.

8. Conlin A, Bhogal S, Sequeira K, Teasell R. Treatment of whiplash-associated disorders - part II: Medical and surgical interventions. Pain Res Manage 2005;10:33-40.

9. Teasell RW, McClure JA, Walton D, et al. A research synthesis of therapeutic interventions for whiplash-associated disorder (WAD): Part 1 - overview and summary. Pain Res Manage 2010;15:287-94.

10. Maher CG, Sherrington C, Herbert RD, Moseley AM, Elkins M. Reliability of the PEDro scale for rating quality of randomized controlled trials. Phys Ther 2003;83:713-21.

11. Byrn C, Borenstein P, Linder LE. Treatment of neck and shoulder pain in whip-lash syndrome patients with intracutaneous sterile water injections. Acta Anaesthesiol Scand 1991;35:52-3.

12. Byrn C, Olsson I, Falkheden L, et al. Subcutaneous sterile water injections for chronic neck and shoulder pain following whiplash injuries. Lancet 1993;341:449-52.

13. Freund BJ, Schwartz M. Treatment of whiplash associated neck pain [corrected] with botulinum toxin-A: A pilot study. J Rheumatol 2000;27:481-4.

14. Juan FJ. Treatment of neck pain after whiplash injuries with botulinum toxin-A injections. J Musculoskelet Res 2003; 7:221-6.

15. Braker C, Yariv S, Adler R, Badarny S, Eisenberg E. The analgesic effect of botulinum-toxin $A$ on postwhiplash neck pain. Clin J Pain 2008;24:5-10.

16. Padberg M, de Bruijn SFTM, Tavy DLJ. Neck pain in chronic whiplash syndrome treated with botulinum toxin. A double blind, placebo-controlled clinical trial. J Neurol 2007;254:290-5.

17. Carroll A. A prospective randomized controlled study of the role of botulinum toxin in whiplash-associated disorder. Clin Rehabil 2008;22:513-9. responses (39). Unfortunately, the majority of studies included in this review were non-RCTs with small sample sizes, generic inclusion criteria, poor methodological design (eg, inadequate length of follow-up) and poor reporting quality (eg, no statistical findings reported). Collectively, these limitations precluded firm conclusions regarding the effectiveness of any surgical or injection-based intervention for patients with chronic WAD. There are overall positive results examining RFN and mixed results for botulinum toxin injections (Table 12). Further research is needed to determine which interventions are most effective for individuals with chronic WAD refractory to more conventional treatment.

18. Teasell RW, McClure JA, Walton D, et al. A research synthesis of therapeutic interventions for whiplash-associated disorder (WAD): Part 3 - interventions for subacute WAD. Pain Res Manage 2010;15:305-12.

19. Barnsley L, Lord SM, Wallis BJ, Bogduk N. Lack of effect of intraarticular corticosteroids for chronic pain in the cervical zygapophyseal joints. N Engl J Med 1994;330:1047-50.

20. Slipman CW, Lipetz JS, Jackson HB, Plastaras CT, Vresilovic EJ. Outcomes of therapeutic selective nerve root blocks for whiplash induced cervical radicular pain. Pain Physician 2001;4:167-74.

21. Slipman CW, Lipetz JS, Plastaras CT, Jackson HB, Yang ST, Meyer AM. Therapeutic zygapophyseal joint injections for headaches emanating from the C2-3 joint. Am J Phys Med Rehabil 2001;80:182-8.

22. Chauhan SK, Peckham T, Turner R. Impingement syndrome associated with whiplash injury. J Bone Joint Surg Br 2003;85-B:408-10.

23. Ettlin T. Trigger point injection treatment with the 5-HT3 receptor antagonist tropisetron in patients with late whiplash-associated disorder. First results of a multiple case study. Scand J Rheumatol Suppl 2004;119:49-50.

24. Hooper RA, Frizzell JB, Faris P. Case series on chronic whiplash related neck pain treated with intraarticular zygapophysial joint regeneration injection therapy. Pain Physician 2007;10:313-8.

25. Ishikawa S, Yokoyama M, Mizobuchi S, Hashimoto H, Moriyama E, Morita K. Epidural blood patch therapy for chronic whiplash-associated disorder. Anesth Analg 2007;105:809-14.

26. Lord SM, Barnsley L, Bogduk N. Percutaneous radiofrequency neurotomy in the treatment of cervical zygapophysial joint pain: A caution. Neurosurgery 1995;36:732-9.

27. Lord SM, Barnsley L, Wallis BJ, McDonald GJ, Bogduk N. Percutaneous radio-frequency neurotomy for chronic cervical zygapophyseal-joint pain. N Engl J Med 1996;335:1721-6.

28. Wallis BJ, Lord SM, Bogduk N. Resolution of psychological distress of whiplash patients following treatment by radiofrequency neurotomy: A randomised, double-blind, placebo-controlled trial. Pain 1997;73:15-22.

29. McDonald GJ, Lord SM, Bogduk N. Long-term follow-up of patients treated with cervical radiofrequency neurotomy for chronic neck pain. Neurosurgery 1999;45:61-7.

30. Carragee EJ, Hurwitz EL, Cheng I, et al. Treatment of neck pain. Injections and surgical interventions: Results of the Bone and Joint Decade 2000-2010 Task Force on Neck Pain and Its Associated Disorders. Spine 2008;33:S153-S169.

31. Sapir DA, Gorup JM. Radiofrequency medial branch neurotomy in litigant and nonlitigant patients with cervical whiplash: A prospective study. Spine 2001;26:E268-E273.

32. Husted DS, Orton D, Schofferman J, Kine G. Effectiveness of repeated radiofrequency neurotomy for cervical facet joint pain. J Spinal Disord Tech 2008;21:406-8.

33. Prushansky T, Pevzner E, Gordon C, Dvir Z. Cervical radiofrequency neurotomy in patients with chronic whiplash: A study of myltiple outcome measures. J Neurosurg Spine 2006;4:365-73. 
34. Liliang PC, Lu K, Hsieh CH, Kao CY, Wang KW, Chen HJ. Pulsed radiofrequency of cervical medial branches for treatment of whiplash-related cervical zygapophysial joint pain. Surg Neurol 2008;70(Suppl 1):S1:50-5.

35. Magnusson T, Ragnarsson T, Bjornsson A. Occipital nerve release in patients with whiplash trauma and occipital neuralgia. Headache 1996;36:32-6.

36. Alpar EK, Onuoha G, Killampalli VV, Waters R. Management of chronic pain in whiplash injury. J Bone Joint Surg Br 2002;84:807-11.
37. Algers G, Pettersson K, Hildingsson C, Toolanen G. Surgery for chronic symptoms after whiplash injury - follow-up of 20 cases. Acta Orthop Scand 1993;64:654-6.

38. Long DM, Davis RF, Speed WG, Hendler NH. Fusion for occult posttraumatic cervical facet injury. Neurosurg Q 2006;16:129-34

39. Ernst E. Towards a scientific understanding of placebo effects. In: Peters D, ed. Understanding the Placebo Effect in Complementary Medicine. Theory, Practice and Research. London: Churchill Livingstone, 2001:17-30. 


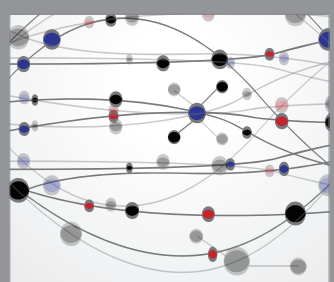

The Scientific World Journal
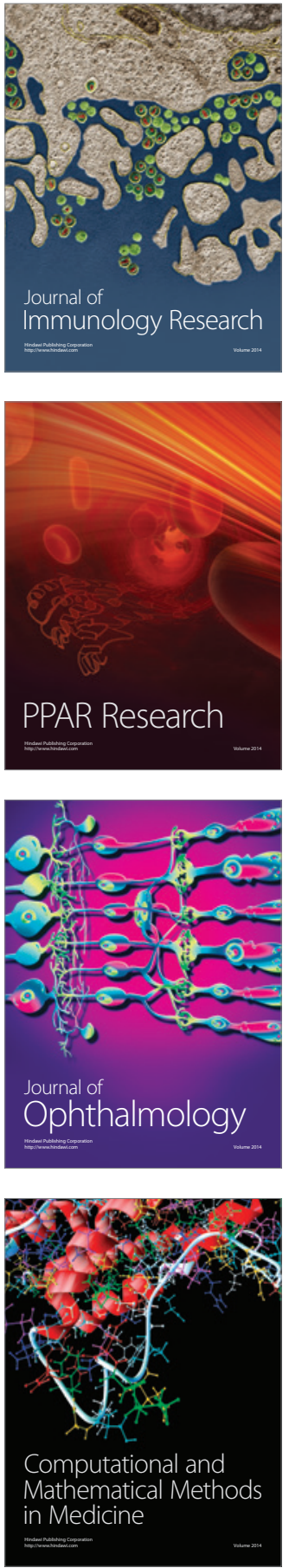

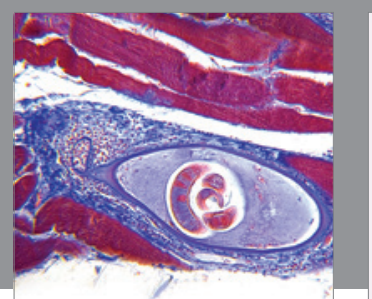

Gastroenterology Research and Practice

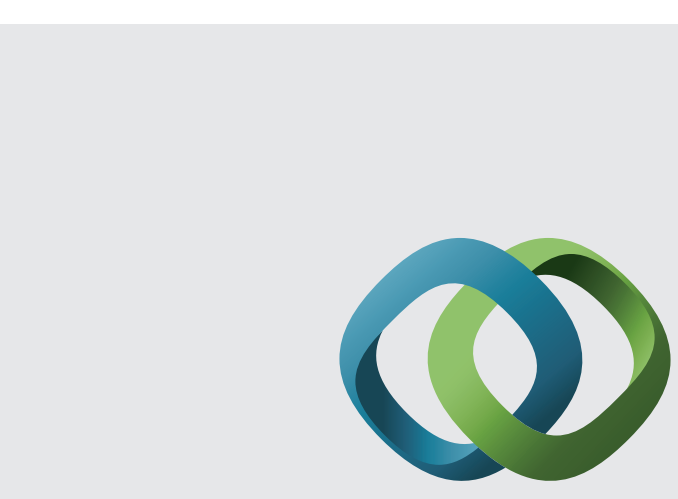

\section{Hindawi}

Submit your manuscripts at

http://www.hindawi.com
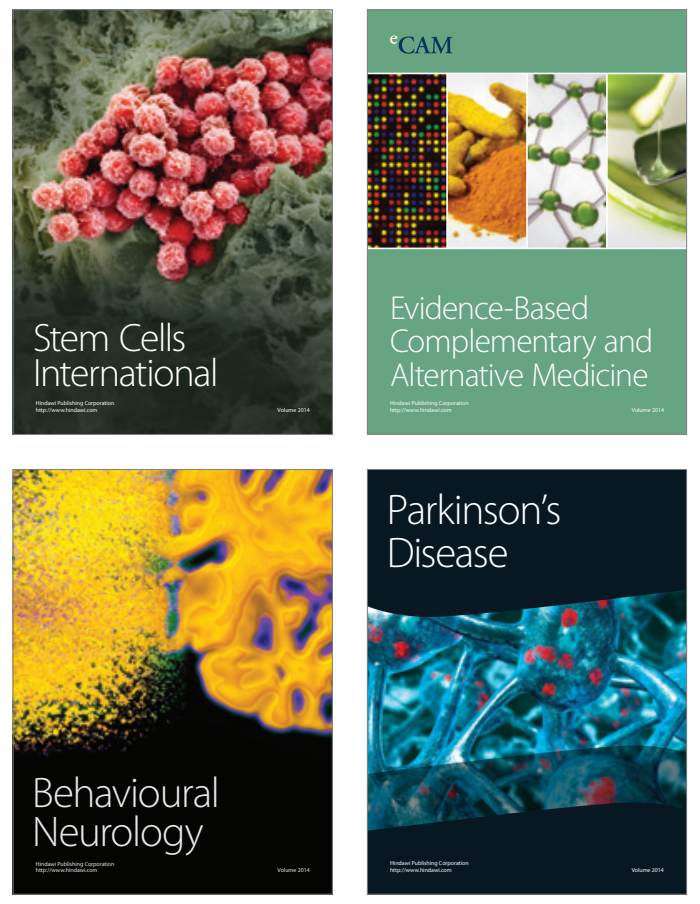
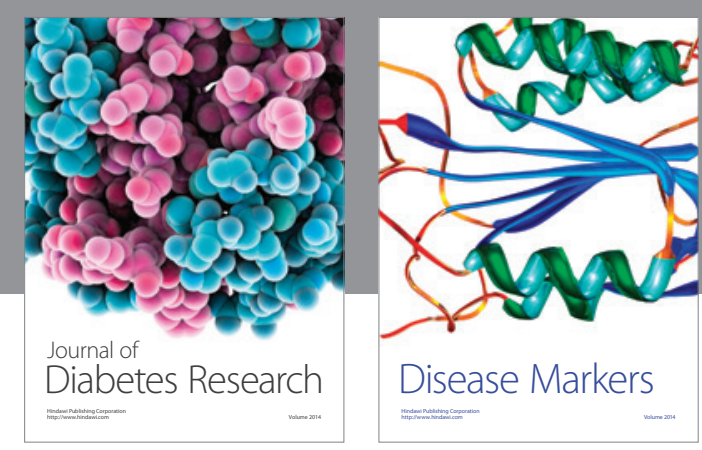

Disease Markers
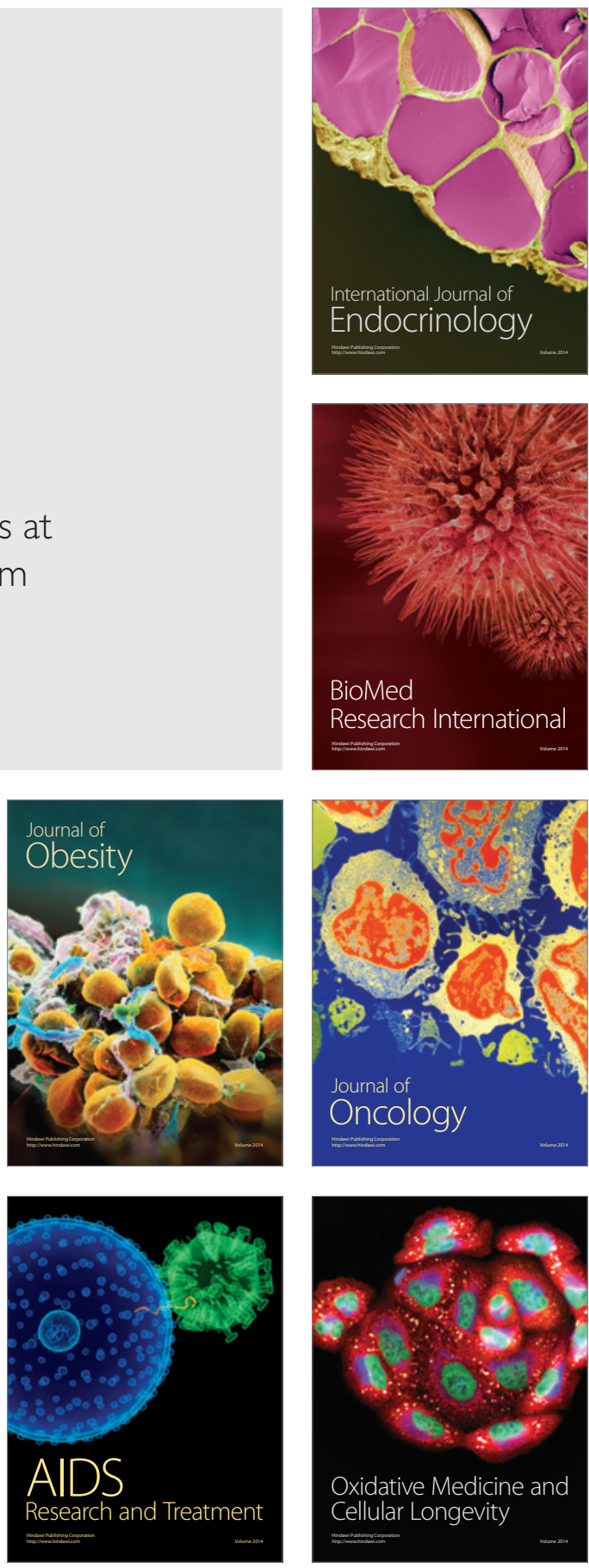